\title{
Antimicrobial and probiotic properties of yeasts: from fundamental to novel applications
}

\author{
Rima Hatoum, Steve Labrie and Ismail Fliss* \\ Nutraceuticals and Functional Foods Institute, STELA Dairy Research Centre, Université Laval, Québec, OC, Canada
}

Edited by:

Min-Tze Liong, Universiti Sains

Malaysia, Malaysia

Reviewed by:

Shao Quan Liu, National University of Singapore, Singapore

Francisco Noé Arroyo López, Instituto de la Grasa, Spain

${ }^{*}$ Correspondence:

Ismail Fliss, Département des

Sciences des Aliments et de

Nutrition, 2425 Rue de l'Agriculture,

Pavillon Paul-Comtois, Université

Laval, Québec, QC, Canada G1V OA6.

e-mail: ismail.fliss@fsaa.ulaval.ca

\begin{abstract}
The yeasts constitute a large and heterogeneous group of microorganisms that are currently attracting increased attention from scientists and industry. Numerous and diverse biological activities make them promising candidates for a wide range of applications not limited to the food sector. In addition to their major contribution to flavor development in fermented foods, their antagonistic activities toward undesirable bacteria, and fungi are now widely known. These activities are associated with their competitiveness for nutrients, acidification of their growth medium, their tolerance of high concentrations of ethanol, and release of antimicrobial compounds such as antifungal killer toxins or "mycocins" and antibacterial compounds. While the design of foods containing probiotics (microorganisms that confer health benefits) has focused primarily on Lactobacillus and Bifidobacterium, the yeast Saccharomyces cerevisiae var. boulardii has long been known effective for treating gastroenteritis. In this review, the antimicrobial activities of yeasts are examined. Mechanisms underlying this antagonistic activity as well as recent applications of these biologically active yeasts in both the medical and veterinary sectors are described.
\end{abstract}

Keywords: yeasts, antagonistic activities, probiotic, killer toxin, mycocin, veterinary, medical

\section{INTRODUCTION}

The term "yeast" was derived originally from the Dutch word " ist," which refers to the foam formed during the fermentation of beer wort. Other words referring to yeast, such as the French word "levure," refer to the role of yeast in causing bread dough to rise. Few other microbial organisms match the yeasts in terms of historical, economic, and scientific significance. In addition to their role in the production of fermented foods and beverages, the yeasts play various roles in livestock feeding and veterinary practices as well as in medicine and the biomedical and pharmaceutical industries. One of these roles consists primarily of antagonizing other microorganisms such as undesirable yeasts, molds, and bacteria.

The inhibitory activity of yeast was discovered first by Hayduck (1909). Somewhat later, other researchers reported the antagonistic action of yeasts against other yeasts, involving the production of secondary metabolites known as killer toxins or "mycocins" (Young and Yagiu, 1978; Rosini and Cantini, 1987; Walker et al., 1995; Suzuki et al., 2001; Marquina et al., 2002). In summarizing the antimicrobial effects of yeasts present in fermented foods and beverages, Viljoen (2006) mentions actions of organic acids, antibiotic factors, volatile acids, hydrogen peroxide, and various other substrates excreted in the product. However, there has been relatively little study devoted to identifying the mechanisms of inhibition by yeasts.

In this chapter, the metabolic factors mentioned above as well as recent advances in knowledge of the antagonistic properties of yeasts will be discussed, with emphasis on the potential opportunities for application in various fields. Although only Saccharomyces cerevisiae var. boulardii has been studied in detail and its inhibitory mechanisms well defined, significant antagonistic activities have been associated with several other genera or species, and exploration of their potential industrial and biotechnological applications is expected.

\section{YEASTS}

\section{GENERAL CONSIDERATION AND TAXONOMY}

The yeasts described in this review are all members of the phylum Ascomycota and the class Saccharomycota. Phylogenetic analysis of the phylum Ascomycota has significantly changed yeast classification in recent years (Hibbett et al., 2007; Kurtzman et al., $2011 \mathrm{a}, \mathrm{b})$. Yeasts are eukaryotic microorganisms widespread in natural environments including the normal microbial flora of humans, on plants, on airborne particles, in water, in food products, and in many other ecological niches. Yeasts are important in many complex ecosystems, as frequent early colonizers of nutrientrich substrates (Kurtzman et al., 2011a,b). They are involved in many interactions with other microorganisms, including symbiosis, mutualism, parasitism, and competition. They also exhibit both asexual and sexual states. The asexual state of given yeast is called the anamorph, while the sexual state is the teleomorph. One result of this phenomenon is that there is a valid Latin name for each state, since no teleomorph has been found for many asexual forms or because the phylogenetic relationship between anamorph and teleomorph has not been confirmed.

The most common mode of vegetative growth of yeasts is by budding, which may be blastic or thallic. Anamorphic and teleomorphic genera may grow either as a "yeast-like" unicellular organism or as a "mold-like" filamentous organism, a phenomenon called dimorphism. Moreover, some species are able to form a true mycelium, while genera such as Candida produce a welldeveloped pseudomycelium, or both pseudo and true mycelium in the case of Candida tropicalis (Goldman, 2008). 
Among the yeasts belonging to the phylum Ascomycota, the genus Saccharomyces is the most studied. Many of the approximately 20 species of this genus are of great biotechnological significance due to applications including alcoholic fermentation, bread-making, single cell protein, vitamin production, synthesis of recombinant proteins, and biological control (Webster and Weber, 2007). The most significant species is certainly S. cerevisiae (baker's and brewer's yeast), due to its economic impact. S. cerevisiae is used for the annual production of an estimated 60 million tons of beer, 30 million tons of wine, 800,000 tons of single cell protein, and 600,000 tons of baker's yeast (Pretorius et al., 2003). The vegetative cells of $S$. cerevisiae are normally diploid, but some strains have been reported as aneuploid or tetraploid (Webster and Weber, 2007). Over the past four decades, a yeast first identified as Saccharomyces boulardii has been studied for its potential probiotic use (Buts, 2009). The taxonomic position of $S$. boulardii was determined using multi locus sequence analysis targeting the D1/D2 domain of the 26S rDNA subunit, the ITS1-5.8S rDNAITS2 sequence, and the mitochondrial cytochrome $\mathrm{C}$ oxidase II (COX2) gene. Each locus is highly similar to the corresponding loci in S. cerevisiae, which led to the proposal to assimilate $S$. boulardii into the $S$. cerevisiae species (Van Der Aa Kühle and Jespersen, 2003). The denomination S. cerevisiae var. boulardii has been proposed, but the designation $S$. boulardii is still largely used in the scientific literature.

\section{YEAST METABOLISM}

Yeasts are heterotrophic organisms, meaning that energy metabolism and carbon metabolism are intimately interconnected. Adenosine triphosphate (ATP) is provided by oxidation of organic molecules that also act as carbon sources for biosynthesis, and is ultimately used as the energetic intermediate for practically all cellular activities (Rodrigues et al., 2006). Yeasts have relatively simple nutritional requirements, a carbon source, a nitrogen source (ammonium salt, nitrate, amino acids, peptides, urea, purines, pyrimidines), phosphate, sulfate, lower concentrations of potassium, magnesium, calcium, iron, zinc, and in most cases a vitamin such as biotin, thiamine, or pantothenic acid making up a complete growth medium. It is well known that the principal carbon source employed by yeasts is carbohydrate, primarily hexose sugars as monosaccharides (glucose, fructose, galactose, or mannose) or disaccharides (maltose or sucrose). In addition, a wide range of other carbon sources (e.g., alcohols, organic acids) can be utilized under aerobic conditions (Deak, 2006).

Van Dijken and Scheffers (1986) classified yeasts physiologically according to the type of energy-generating process involved in sugar metabolism, namely non-fermentative, facultatively fermentative, or obligately fermentative. It was later found that basidiomycetous yeasts such as Cryptococcus, Rhodotorula, and others are non-fermentative and strictly aerobic (Goldman, 2008). Not even the obligate fermentative species can survive for very long under strict anaerobic conditions, since the synthesis of certain membrane constituents (i.e., sterols) requires oxygen (Deak, 2006). Yeast metabolism and physiology are thus strongly dependent on sugar and oxygen availability. Yeast aerobic respiration has been defined by Dawes (1986) as the complete oxidation of carbon-containing molecules to $\mathrm{CO}_{2}$ and $\mathrm{H}_{2} \mathrm{O}$ by the interrelated processes of the tricarboxylic acid (TCA) cycle and the electron transport chain coupled to phosphorylation with oxygen as the terminal electron acceptor. In yeast anaerobic metabolism, often called "alcoholic fermentation," pyruvate produced by glycolysis is split into ethanol and $\mathrm{CO}_{2}$ in a redox-neutral process (Van Dijken and Scheffers, 1986).

Finally, there are three frequently observed effects associated with the type of energy-generating processes involved in sugar metabolism and/or oxygen availability; Pasteur, Cabtree, and Custer effect (Van Dijken and Scheffers, 1986; Fredlund et al., 2004; Dickinson and Kruckeberg, 2006; Wijsman et al., 1984). Due to its industrial importance, better understanding of yeast metabolism is needed in order to provide insight into the formation of primary and secondary metabolites and their impact on human health.

\section{ANTAGONISTIC CHARACTERISTICS OF YEASTS}

The use of antagonistic bacteria to inhibit pathogenic bacteria has been studied extensively over the years, while little attention has been given to yeasts in a similar role. The study and potential applications of antibacterial compounds secreted by yeasts are therefore still at an early stage of development.

Antagonism of microorganisms by yeasts has been attributed primarily to (1) competition for nutrients, (2) $\mathrm{pH}$ changes in the medium as a result of growth-coupled ion exchange or organic acid production, (3) production of high concentrations of ethanol, (4) secretion of antibacterial compounds and release of antimicrobial compounds such as killer toxins or "mycocins" (Suzuki et al., 2001; Golubev, 2006; Young and Yagiu, 1978). Mycocins are extracellular proteins or glycoproteins that disrupt cell membrane function in susceptible yeasts, which bear receptors for the compound (Golubev, 2006). Their activity is directed primarily against yeasts closely related to the producer strain, which has a protective factor. The first mycocins were identified in association with $S$. cerevisiae in the brewing industry (Bevan and Somers, 1969). Several have since been isolated, frequently where yeast populations exist in high density and in highly competitive conditions. Mycocin production occurs among many yeast genera including Saccharomyces, Candida, Cryptococcus, Debaryomyces, Kluyveromyces, Pichia, Torulopsis, Williopsis, and Zygosaccharomyces (Young and Yagiu, 1978; Magliani et al., 1997; Chen et al., 2000; Schmitt and Breinig, 2002; Golubev, 2006; Hodgson et al., 1995). Genetic and molecular studies have shown that the killer toxin trait may be carried on extra-chromosomal elements in the form of double-stranded RNA viruses (Wickner, 1996), on double-stranded linear DNA (Gunge et al., 1981; Hayman and Bolen, 1991), or on a chromosome (Kimura et al., 1993; Suzuki and Shimma, 1999). The well known mechanisms of the killer toxin are the interruption of cell division by blocking the DNA synthesis, inhibition of synthesis of the cell wall component $\beta$ 1,3-glucan (Izgu and Altinbay, 2004), and ion leakage caused by the formation of channels on the cytoplasmic membrane (Kagan, 1983; Schmitt and Breinig, 2002; White et al., 1989; Figure 1). Unlike yeast-against-yeast antagonism, the antibacterial properties of yeast are much less documented.

Historically, the first positive indications of the antagonistic activity of yeasts published early in the twentieth century by Hayduck (1909) and Fernbach (1909; cited in Golubev, 2006) who reported a volatile thermolabile toxic extract from yeast probably 


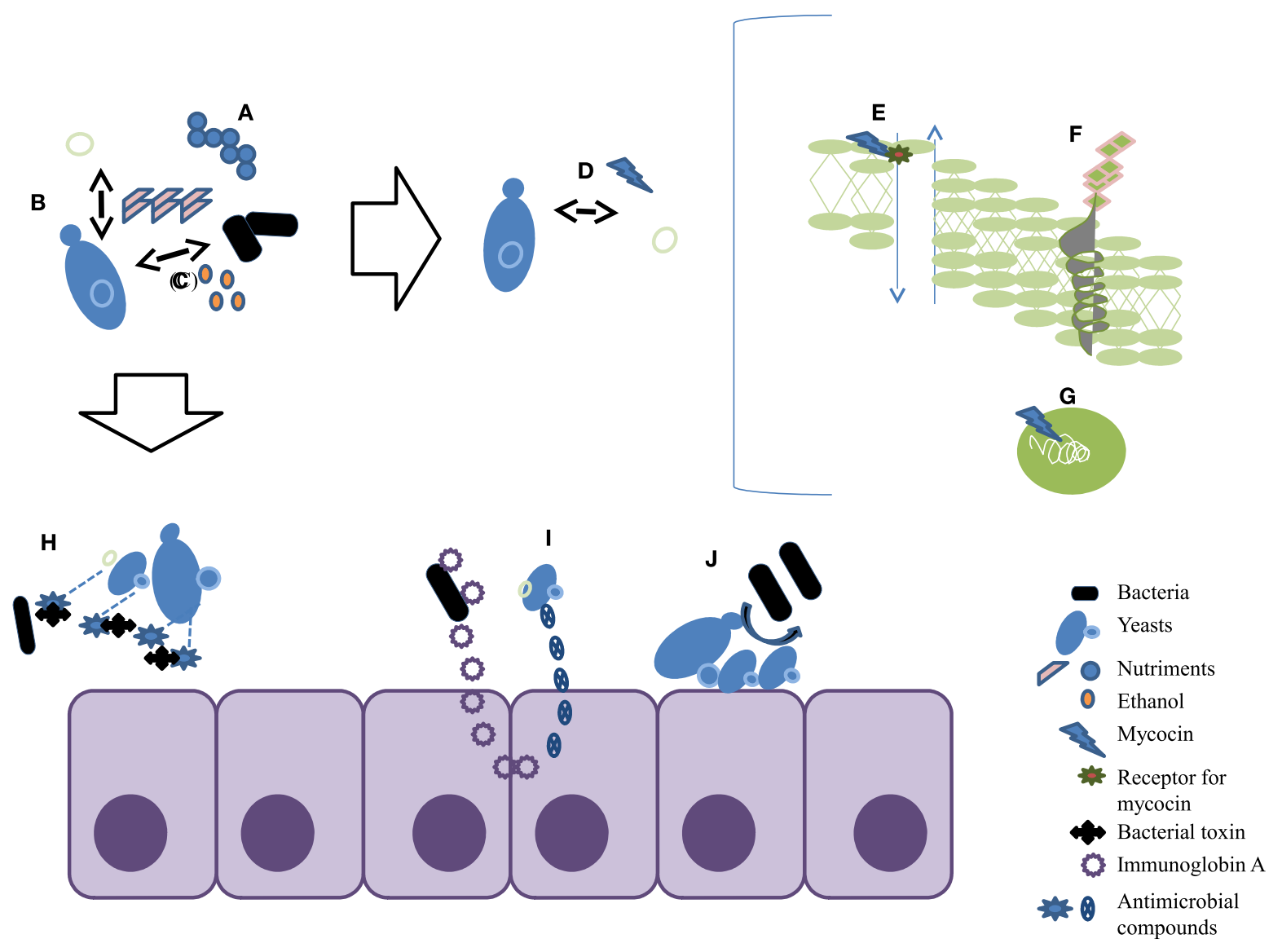

FIGURE 1 | Summary of the different aspects of antagonistic properties of yeasts. (A) Competition for nutrients; (B) pH changes; (C) production of high concentrations of ethanol; (D) killer toxins or mycocins; (E) mycocin causes ion leakage by the formation of channels on the cytoplasmic membrane; (F) mycocin inhibits the synthesis of cell wall component $\beta$-1,3-glucan; (G) mycocin interrupts cell division by blocking the DNA synthesis; (H) proteases degrade bacterial toxins; (I) stimulate the immune response; (J) yeasts inhibit attachment to intestinal cells. an amine that inhibits the growth of Escherichia coli and Staphylococci (Viljoen, 2006). Fatichenti et al. (1983) showed that the antibacterial activity of Debaryomyces hansenii against Clostridium tyrobutyricum and Clostridium butyricum was related to its ability to produce both extracellular and intracellular antimicrobial compounds. Bilinski and Casey (1989) reported inhibition of the growth of the beer spoilage bacteria Bacillus megaterium and Lactobacillus plantarum due to the conversion of methylene blue into a pharmacologically active form by Kloeckera apiculata and Kluyveromyces thermotolerans. Dieuleveux et al. (1998) subsequently described inhibition of Listeria by a strain of Geotrichum candidum isolated from French red smear cheese. The two anti-listerial compounds ( $\mathrm{D}-3$-phenyllactic and $\mathrm{D}$-3-indollactic acids) are stable over a wide $\mathrm{pH}$ range and can be heated to $120^{\circ} \mathrm{C}$ for $20 \mathrm{~min}$. Also, Cavalero and Cooper (2003) demonstrated that Candida bombicola produces extracellular glycolipids called sophorosides, which have proven antibacterial activity against Staphylococcus aureus and also inhibit Candida albicans. Having tested hundreds of dairy yeasts, Goerges et al. (2006) reported a strain of Candida intermedia capable of reducing viable Listeria counts by $4 \log \mathrm{CFU} / \mathrm{cm}^{2}$ in co-culture on agar, while three $C$. intermedia and one Kluyveromyces marxianus suppressed L. monocytogenes growth by $3 \log \mathrm{CFU} / \mathrm{cm}^{2}$. The same group more recently found a strain of Pichia norvegensis (WSYC 592) able to reduce $L$. monocytogenes counts by 7 log cycles, while numerous strains of Issatchenkia orientalis, Candida krusei, and K. marxianus reduced Listeria counts by 4-5 log units in co-culture on agar (Goerges et al., 2011). However, strain WSYC 592 decreased Listeria counts on Tilsit cheese by only one log cycle. More recently, Hatoum et al. (2012) characterized anti-listerial hydrophobic peptides extracted from cultures of four wild dairy yeasts identified as D. hansenii, $P$. fermentans, C. tropicalis, and W. anomala. In experiments using a Camembert curd model, the anti-listerial compounds of $D$. hansenii and $W$. anomalus were found to reduce $L$. monocytogenes counts by $3 \log$ units during the first 9 days of ripening. The active principles are thermostable and apparently peptides and appear to induce leakage in bacterial cells and ultimately cause bacterial lysis (Figure 2).

\section{APPLICATIONS OF ANTAGONISTIC ACTIVITIES OF YEASTS}

The discovery of antagonistic activities of yeasts has had a significant impact in numerous fields such as food, agriculture, medicine, 


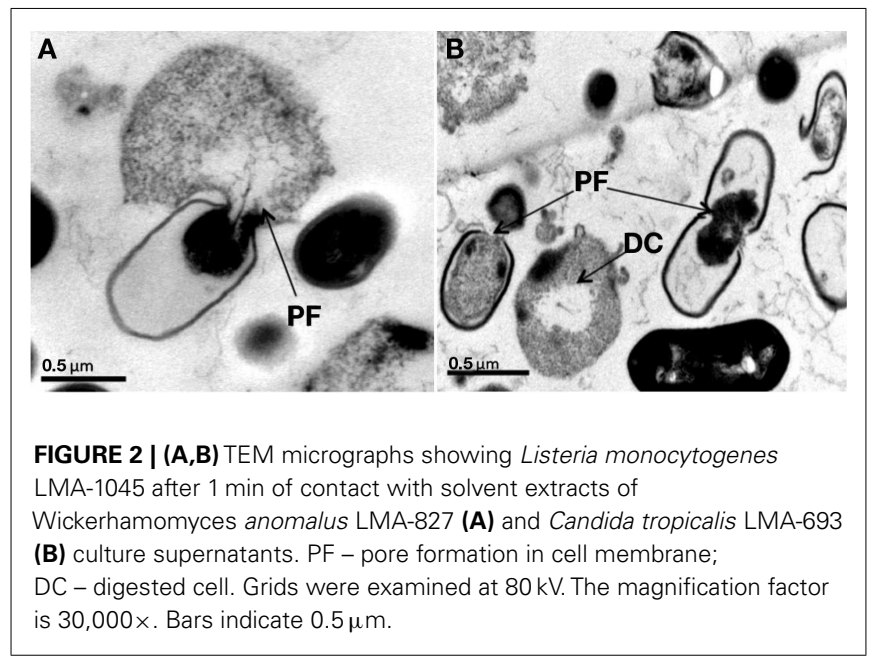

veterinary medicine, environmental protection, and others. The following sections of this paper provide an updated summary of published findings regarding the antagonistic properties of yeasts. Figure 3 presents an organogram in which the applications are grouped in three different clouds in a free-mind program http: //bactibase.pfba-lab-tun.org/freemind/. The articles are linked to these three clouds.

\section{FOOD AND AGRICULTURE}

\section{Processed food and beverages applications}

The past decades have witnessed the application of antagonistic yeast starter cultures in various food processing industries. It is well known that final product quality in industries such as wine-making, sausage production, cheese ripening, bakery, and the "fermentations" of cacao and coffee beans is affected directly by the development of spoilage microorganisms (Romano et al., 2006; Viljoen, 2006). Antagonistic yeasts starter cultures contribute to product safety primarily by inhibiting pathogen growth during fermentation, and to finish product sensory qualities and shelf-life by inhibiting spoilage organisms.

Numerous studies have proposed the use of mycocinproducing yeasts as starter cultures to prevent the growth of spoilage yeast strains and secondary fermentation wines (Hara et al., 1980; Pfeiffer and Radler, 1984; Boone et al., 1990; Van Vuuren and Jacobs, 1992; Comitini et al., 2004a,b; Seki et al., 1985). A wine starter culture such as S. cerevisiae is normally able to dominate native yeasts in the grape must during fermentation (Pretorius, 2000). Also, in the production of sparkling wine, Todd et al. (2000) studied the behavior of two sensitive strains of $S$. cerevisiae in the presence of a mixture of two K2 killer toxin. The authors concluded that this interaction accelerates the yeast autolysis and per consequence the release of proteins that affects the end product quality. Although $S$. cerevisiae strains that produce $\mathrm{K} 2$ toxins have been found effective for preventing the growth of spoilage yeast strains (Pfeiffer and Radler, 1984; Van Vuuren and Jacobs, 1992), numerous non-Saccharomyces yeasts present on the surface of grapes are insensitive to the S. cerevisiae killer toxins. Killer toxins secreted by Kluyveromyces phaffii $(\mathrm{KpKt})$ are strong inhibitors of Hanseniaspora uvarum (Ciani and Fatichenti,
2001; Michalcáková et al., 1993) and thus appeared to have biopreservative properties potentially useful for the wine industry. Years later, Comitini et al. (2004a,b) purified and characterized a glycosylated $33 \mathrm{KDa}$ protein produced by $K$. phaffii and found that it binds to $\beta$-1,3-glucan, causing the formation of pores in the cell walls of wine spoilage yeasts. They also showed that killer toxins secreted by W. anomalus and Kluyveromyces wickeramii inhibit Dekkera and Brettanomyces, spoilage yeasts that cause unpleasant odors in wine. Numerous studies have confirmed remarkable inhibitory properties of the killer toxin NCYC 432 (49 kDa glycosylated peptide) of W. anomalus and the mycosin HMK of Williopsis markii (Ibeas et al., 1996; Izgu and Altinbay, 2004; Izgu et al., 2006; Lowes et al., 2000) against a wide range of pathogenic and spoilage fungi. The antagonistic properties of yeast can also influence the interactions of wine yeast and malolactic bacteria mainly Oenococcus oeni. In particular, this interaction between yeast and bacteria can stimulate or prevent the progress of malolactic fermentation which improves wine stability and quality (Alexandre et al., 2004).

Applications of the mycocin-producing yeasts have been suggested also for olive fermentation (Llorente et al., 1997; Asehraou et al., 2007; Hernández et al., 2008; Marquina et al., 1992); beer production (Young, 1981) sake production (Yoshiuchi et al., 2000), and in salted fermented foods such as miso, soy sauce, and salted vegetables (Kono and Himeno, 1997; Suzuki et al., 2001). It has been reported that the inhibitory activity of $D$. hansenii is enhanced by the presence of $\mathrm{NaCl}$ (Llorente et al., 1997), which enhance the cell membrane porosity. This phenomena has also been reported in dough production (Almeida and Pais, 1996) and bread (Bortol et al., 1986). Uses of mycocin-producing starter yeasts to prevent spoilage in yogurt (Lowes et al., 2000; Liu and Tsao, 2009b,c, 2010a,b), probiotic cheese (Jakobsen and Narvhus, 1996), and other foods (Palpacelli et al., 1991) have also received attention.

In spite of their potential benefits in terms of food preservation, mycocin-producing yeasts should be used with caution. The strain might have a negative impact on end product quality, as has been observed for cheese (Valdés-Stauber et al., 1997; Wyder and Puhan, 1999) and wine (Fleet, 2007). Some strains have developed super killer toxins and their escape into the natural environment could threaten other industrial fermentation processes (Magliani et al., 2005). Given the wide range of biotechnological applications of antagonistic yeasts, further studies are required to standardize inoculation parameters and maximize end product stability.

\section{Bio-control in unprocessed foods}

The antagonistic properties of yeasts have been used in numerous promising agricultural applications as natural bio-control agents, both as soil treatments and for preventing diseases in preand post-harvest crops. In 1995, the USA environmental protection agency registered Candida oleophila as bio-control postharvest yeast (El-neshawy and Wilson, 1997). This application has been discussed in numerous studies (Walker et al., 1995; Lowes et al., 2000; Masih et al., 2001; Masih and Paul, 2002; Santos and Marquina, 2004; Spadaro and Gullino, 2004; Kitamoto et al., 1999). 


\section{MEDICAL APPLICATIONS Probiotics}

One of the most significant non-process uses of yeasts is as probiotic microorganisms. The Food and Agriculture Organization (FAO) of the World Health Organization (WHO) defines probiotics as "live microorganisms which when administered in adequate amounts confer a health benefit on the host" (FAO/WHO, 2002). For many years, probiotics were used only in animal feeds. Various authors have shown that surplus biomass from the fermentation industry, recycled as an additive to cattle, hog, and poultry diets, improves livestock performance and product quality (Dawson et al., 1990; Li et al., 2006; van Heugten et al., 2003). It was hypothesized that the yeast $S$. cerevisae provides vitamins B and organic acids that stimulate the rumen acetogens (Chiquette, 2009) which form acetic acid (a utilizable form of carbon) from hydrogen and carbon dioxide.

First isolated from litchi fruit in Indochina and described in 1984 as a saprophytic yeast, S. cerevisiae var. boulardii has emerged as a probiotic species for human consumption (Van Der Aa Kühle et al., 2005). This strain has also been recommended for the prevention and treatment of several types of gastroenteritis in children and adults (Kurugöl and Koturoglu, 2005; Htwe et al., 2008). Nowadays, probiotic yeasts can be delivered either in fermented foods or as lyophilized cultures administered orally, for example, to patients who have been hospitalized as a consequence of severe diarrhea. Several yeast species, including D. hansenii, Torulaspora delbrueckii (Psani and Kotzekidou, 2006), Kluyveromyces lactis, Yarrowia lipolytica (Chen et al., 2010), K. marxianus, K. lodderae (Kumura et al., 2004) have been found strongly antagonistic to pathogenic bacteria and to tolerate passage through the gastrointestinal tract. In a recent in vitro study, Etienne-Mesmin et al. (2011) investigated the probiotic effect of S. cerevisiae CNCM I3856 against E. coli O157:H7. The results showed that the probiotic yeast exert the antagonistic effects in the distal part of the small intestine and that might be due to ethanol production. However, only S. boulardii is considered as a probiotic (Czerucka et al., 2007). Its probiotic efficiency has been well documented in numerous clinical studies (Sazawal et al., 2006).

The text that follows describes the various mechanisms that underlie the probiotic activities of $S$. boulardii against a variety of pathogens such as Escherichia coli, Vibrio cholera, Clostridium difficile, and Samonella in clinical and animal studies.

Antibiotic associated diarrhea "AAD". Antibiotic therapy is well known to destroy the normal bacterial population of the digestive tract, which allows harmful bacteria to colonize and irritate the host gut and cause antibiotic associated diarrhea (Coté and Buchman, 2006). Numerous placebo-controlled clinical studies have shown the beneficial effects of $S$. boulardii in preventing antibiotic associated diarrhea (D'Souza et al., 2002; Erdeve et al., 2004; Duman et al., 2005; Kotowska et al., 2005; Can et al., 2006; Cindoruk et al., 2007; Whelan, 2007; Bravo et al., 2008; Lewis et al., 1998). In a double-blind study, Adam et al. (1976) reported a significant reduction in AAD symptoms in the group that received $200 \mathrm{mg}$ of S. boulardii ( $10^{9} \mathrm{CFU} /$ day) for 7 days. Only $4.5 \%$ of this group developed $\mathrm{AAD}$, compared to $17.5 \%$ of the placebo group. In a study involving 193 hospitalized patients receiving $\beta$-lactam antibiotics (Mcfarland et al., 1994), one group received $1 \mathrm{~g}$ of $S$. boulardii while the other was given a placebo, both for periods lasting 3 days beyond the antibiotic treatment. AAD appeared in $7.2 \%$ of the $S$. boulardii group compared to $14.6 \%$ $(P<0.05)$ of the placebo group. In a study of the effect of $200 \mathrm{mg}$ of $S$. boulardii ( $10^{9} \mathrm{CFU} /$ day) for 2 weeks beyond the antibiotic treatment, Surawicz et al. (1990) reported AAD in $9.5 \%$ of the probiotic-treated group versus $21.8 \%(P<0.05)$ in the placebo group. In a study (involving 151 patients) of the preventive effect of $S$. boulardii given only for the duration of the antibiotic treatment, Can et al. (2006) found AAD in 1.4\% of the probiotic-treated group versus $9.0 \%$ in the placebo group. Similar results have been obtained by Cremonini et al. (2002) and Duman et al. (2005).

Clostridium difficile associated diarrhea. The effects of S. boulardii on $C$. difficile have also been studied. $C$. difficile is responsible for $20 \%$ of antibiotic associated diarrhea cases (Kelly et al., 1994; Krämer and Bischoff, 2006) and causes pseudomembranous colitis, an infection of the colon. There are only two standard antibiotics for $C$. difficile infection, namely vancomycin and metronidazole, and the response rate to the later has been declining (McFarland, 2007). S. boulardii in combination with antibiotics has been shown effective for treating $C$. difficile associated diarrhea and colitis (Mcfarland et al., 1994; McFarland, 2010; Surawicz et al., 2000). In a randomized placebo-controlled trial of 124 patients suffering from C. difficile infection (Mcfarland et al., 1994), standard antibiotics were combined with S. boulardii ( $500 \mathrm{mg}$ /day) or placebo. Patient follow-up revealed a significant reduction in $C$. difficile infection reoccurrence in those treated with S. boulardii (34.6\% compared to $64.7 \%$ for the placebo, $P=0.04$ ). In a similar study involving 170 patients (Surawicz et al., 2000), reoccurrence in the $S$. boulardii-treated group was $16.7 \%$ compared to $50 \%$ for the placebo group $(P=0.05)$. In a more recent comparison of the efficacy of a mixture of probiotics, McFarland et al. (2006) concluded that only S. boulardii was effective against C. difficile infection.

The effects of S. boulardii have also been studied in vitro and in animal models such as gnotobiotic mice (Elmer and Corthier, 1991; Elmer et al., 1999; Castex et al., 1990) rats (Karen et al., 2010; Sezer et al., 2009), and turkeys (Bradley et al., 1994). Czerucka and Rampal (2002) linked the effects of S. boulardii to the production of a $54-\mathrm{KDa}$ protease. Its mechanism appears to degrade $C$. difficile toxins (Castagliuolo et al., 1996; Qamar et al., 2001), and could do likewise to the colonic cell surface receptors for $C$. diffcile (Pothoulakis et al., 1993; Castagliuolo et al., 1996; Pothoulakis, 2009; Castagliuolo et al., 1999), or otherwise inhibit C. difficile attachment to intestinal cells (Buts and Bernasconi, 2005; Buts, 2009; Tasteyre et al., 2002). S. boulardii also appears to increase the immune response to C. difficile toxins A and B (Buts, 2009). It has been demonstrated that $S$. boulardii stimulates an increase in intestinal immunoglobin A secretion during a C. difficile toxin A challenge in mice (Qamar et al., 2001; Figure 1).

Traveler's diarrhea. Each year million of people worldwide develop traveler's diarrhea. S. boulardii activities in the prevention of traveler's diarrhea have been widely investigated. In 1016 travelers visiting various countries in the world Kollaritsch et al. (1993) 
reported a significant reduction in diarrhea among patients receiving 5 billion CFU of $S$. boulardii/day (34\% versus $40 \%$ in patients receiving placebo $P=0.019$ ). Based on analysis of 12 studies of the use of probiotics to prevent traveler's diarrhea, McFarland (2007) reported a significant benefit of two probiotics, namely $S$. boulardii and a mixture of Lactobacillus acidophilus and Bifidobacterium bifidum.

Acute diarrhea in adults and children. Every year, an estimated 2 million deaths worldwide occur as a result of acute diarrhea (Billoo et al., 2006). Several studies have shown the beneficial effects of $S$. boulardii in preventing acute diarrhea. In a group of 50 children (aged 2 months to 2 years) receiving 10 billion CFU of $S$. boulardii/day or a placebo in combination with oral rehydration salt and nutritional support, Billoo et al. (2006) showed significant reductions in stool frequency and duration of diarrhea in the $S$. boulardii group compared to the placebo group. In a double-blind randomized study, Kurugöl and Koturoglu (2005) noted a significant reduction in the number of days with diarrhea and hospitalization among 200 children treated with S. boulardii. Similar results were found in another double-blind randomized study by Villarruel et al. (2007).

Tube-feeding-associated diarrhea. DeMeo et al. (1998) estimated that approximately $68 \%$ of tube-fed patients develop diarrhea. Several studies suggest the beneficial effects of $S$. boulardii in restoring normal intestinal microflora and preventing tubefeeding-associated diarrhea. In a double-blind placebo-controlled trial involving 40 tube-fed patients, a 50\% reduction in days with diarrhea was observed among patients given $S$. boulardii compared to the placebo group (Tempé et al., 1983). Another double-blind placebo-controlled study following 128 critically ill tube-fed patients (Bleichner et al., 1997) showed a significant but small reduction in days with diarrhea among patients given 40 billion CFU of $S$. boulardii four times/day (14.2 versus $18.9 \%$ in patients receiving placebo).

Inflammatory bowel disorders. Inflammatory bowel diseases (IBD), Crohn's disease, ulcerative colitis and Irritable bowel syndrome are chronic inflammatory disorders of the gastrointestinal tract. Numerous studies showed that $S$. boulardii hold promise for the treatment of inflammatory bowel disorders. In a doubleblind study of 20 patients suffering from Crohn's disease (Plein and Hotz, 1993) showed a significant reduction in the bowel movement among patients receiving $S$. boulardii in addition to their conventional therapy. In a single-blind study of 32 patients with Crohn's disease (Guslandi et al., 2000), similar results were reported for patients receiving $S$. boulardii $\left(20 \times 10^{9} \mathrm{CFU} /\right.$ day $)$ compared to patients receiving $500 \mathrm{mg}$ of mesalazine three times daily. Guslandi et al. (2003) reported improvement of $68 \%$ of patients with ulcerative colitis receiving mesalazine $(3 \mathrm{~g} /$ day $)$ and $250 \mathrm{mg}$ of $S$. boulardii in capsules three times daily for 4 weeks. Finally, $S$. boulardii has been shown to exert promising beneficial effect in the treatment of IBD. One suggested mechanism unique action on inflammation by specific alteration of the migratory behavior of $\mathrm{T}$ cells, which accumulate in mesenteric lymph nodes (Dalmasso et al., 2006a,b). S. boulardii treatment might thus limit the infiltration of T-helper 1 cells, and hence colonic inflammation and amplification thereof by pro-inflammatory cytokines.

Further in vivo studies are required to investigate the ability of various yeasts strain to exercise their probiotic effect (Foligné et al., 2010). Also, further studies are requiring an optimal and controlled probiotic formula to enhance the biotherapeutic effects of yeast.

Chronic diarrhea in human immunodeficiency virus and others. In a randomized double-blind study of 35 patients with AIDS-related diarrhea, Saint-Marc et al. (1995) reported a reduction in diarrhea among patients receiving $S$. boulardii (3 g/day for 7 days). After 1 week of treatment with $S$. boulardii, $61 \%$ of the patients were diarrhea-free compared with $12 \%$ in the placebo group. Finally, other studies revealed the efficacy of $S$. boulardii to reduce diarrhea in people suffering from giardiasis (Besirbellioglu et al., 2006), amebiasis (Mansour-Ghanaei et al., 2003; Tanyuksel and Petri, 2003) where S. boulardii reduces the number of red cells adhering to amoeba and the number of amoebae bearing red cells (Rigothier et al., 1994), and Helicobacter pylori gastritis (Duman et al., 2005). It was reported that $S$. boulardii had improved the post-treatment dyspepsia symptoms of $H$. pyloris infection without having a significant effect on the rate of $H$. pylori eradication (Cindoruk et al., 2007). Recently, Vandenplas et al. (2009) suggested that $S$. boulardii alters the structure of $H$. pylori. Further studies are required for better understanding of yeast probiotics mechanisms.

Probiotic bacteria/yeast interaction. Because probiotic yeast and bacteria have different mechanisms of action, a synergetic effect and higher viability might be expected from mixing both types of probiotics (Bisson et al., 2010 and Suharja et al., 2012). Several studies showed that yeasts could positively interact with probiotic bacterial by enhancing their survival and stimulating their growth (Gobbetti et al., 1994; Liu and Tsao, 2009a,b,c; Katakura et al., 2010; Suharja et al., 2012). This positive interaction between yeast and bacteria might be attributed to the production of nutrients such as peptides, amino acids, and/or vitamins (Gobbetti et al., 1994; Viljoen, 2001, 2006; Narvhus and Gadaga, 2003; Kawarai et al., 2007; Katakura et al., 2010). It is well known that the cell wall of yeasts is mainly composed of glucans, mannans, and chitin, all of which may play a role in co-aggregation and cohesion phenomena which play a major role in the survival of probiotic bacteria (Chaffin et al., 1998; Millsap et al., 1998). Aggregation may involve the yeast mannans form a capsule-like structure where bacteria may associate with sugars by means of a lectin-like (Millsap et al., 1998). Katakura et al. (2010) identified proteins on the surface of Lactococcus lactis IL1403, which recognize the yeast mannan involved in adhesion of lactic acid bacterium to the yeast. Also, in the study of interactions between microorganisms present in kefir grains, Golowczyc et al. (2009) showed that thermolabile non-covalently lectin-like surface proteins of several Lactobacillus kefir strains can mediate the aggregation with S. liplytica CIDCA 812 yeast cells. It has been hypothesized by Xie et al. (2012) that the aggregation of LAB with yeasts in gastric or intestinal juices might have positive effects on enhancing the tolerance of LAB. The same group concluded that proteins of the cell surface of Labacillus paracasei 
$\mathrm{H} 9$ and polysaccharides in cell walls of $S$. cerevisiae play important roles in co-aggregation of the two strains and the microbial adhesion specificity to Caco-2 cells that contributes to enhancing probiotic potentials of L. paracasei H9. Also, Liu and Tsao (2010a,b) reported that the use of Williopsis saturnus var. saturnus enhances the survival of the two probiotic bacteria L. bulgaricus and L. rhamnosus in fermented milk. The same group concluded that the use of yeast enhance the stability of probiotic bacteria in fermented milk thereby extend the product shelf-life and retain nutritional value (Liu and Tsao, 2010a,b).

\section{Other medical application}

The relatively recent discovery of bio-drug effects of yeasts potentially opens a door to new clinical applications. Blanquet et al. (2001) defined bio-drugs as orally administered living recombinant microorganisms that express disease-fighting proteins. The application of non-recombinant yeast as antimycotics for therapeutic treatment of human and animal fungal infection has also received considerable attention (Polonelli et al., 1986; Hodgson et al., 1995; Séguy et al., 1998; Conti et al., 2002; Schmitt and Breinig, 2002). The killer toxin of L. mrakii has been proposed as an antifungal compound against Candida spp., due to its similarity to aculeacin and stability to $\mathrm{pH}$ and temperature changes (Walker et al., 1995; Hodgson et al., 1995). Weiler and Schmitt (2003) found that the zygocin, produced by Zygosaccharomyces bailii, has a rapid killing effect against a wide range of pathogenic yeasts including Candida albicans, Candida glabrata and Candida krusei, and Sporothrix schenckii based on disruption of membrane ion gradients. However, it is important to note that killer toxins are large glycoprotein compounds and hence capable of inducing an immune response in the host. To deal with this potential challenge, several strategies have been proposed. For example, Magliani et al. (1997) synthesized small non-antigenic peptides with killer activity. The same group suggested the utilization of an anti-idiotypic antibodies from killer toxin secreted by $W$. anomalus (Magliani et al., 2008). These "antibiobodies" (i.e., immunoglobulin molecules acting directly to provide passive immunity without involvement of other immune system factors) showed a significant microbicidal activity against wide range of pathogenic agents through the interaction with specific killer toxin receptors composed by beta-glucans. A novel antifungal vaccine derivative of W. anomalus killer toxin ( $\mathrm{PaKT}$ ) has been described recently by Polonelli et al. (2011).

\section{VETERINARY APPLICATIONS}

Yeast as a source of protein, vitamins, and minerals in animal feeds and for veterinary use has a long history (Anupama and Ravindra, 2000; Bekatorou et al., 2006). Yeast single cell protein is effective for accelerating growth and improving the well-being of cattle by stimulating rumen acetogens (Halász and Lásztity, 1991; Klein and Favreau, 1995; Kurtzman et al., 2011a,b). The use of yeast cell wall polysaccharides as adjuncts for animal and fish feeds has been found to improve the health of growing pigs (Sauerwein et al., 2007). Increasing resistance of bacterial pathogens to antibiotics, due largely to overuse of these compounds in livestock production, has fueled the search for alternative strategies such as probiotics to ensure animal health (Dawson et al., 1990; Li et al., 2006; van Heugten et al., 2003). S. cerevisiae was has been used in many probiotic preparations (Lyons et al., 1993; Edens, 2003; Swanson et al., 2002a,b). Yeast may act by various mechanisms such as modulation of immune system, histamine release (Holck et al., 2007), binding to toxins, and to pathogenic cell (Castex et al., 1990; Elmer and Corthier, 1991; Elmer and McFarland, 1987), interactions with gut constituents, and anti-tumor activities (Ghoneum et al., 2007).

Several studies of poultry have shown that $S$. boulardii increases bird weight when used as a feed supplement during the early stages of life (Bradley et al., 1994; Hooge, 2004; Gao et al., 2008; Patterson and Burkholder, 2003). Investigating the effect of 1$100 \mathrm{~g}$ of dried S. boulardii/kg of feed, Line et al. (1998) found that colonization of the cecum of broiler chickens challenged with Salmonella typhimurium $\left(3.2 \times 10^{8} \mathrm{CFU}\right)$ was $5-20 \%$ and inversely proportional to the amount of yeast given, compared to $70 \%$ in birds not fed the yeast. Investigating the impact of viable cells $\left(6.5 \times 10^{10} \mathrm{CFU} / \mathrm{kg}\right.$ of feed), extract, or cell wall of $\mathrm{S}$. cerevisiae on growth, meat quality, and ileal mucosal development in male broiler chickens, Zhang et al. (2005) concluded that whole yeast improved growth rate as well as meat tenderness and oxidative stability, while cell wall improved ileal mucosal development only. Other authors have obtained similar results with broiler chickens and other animals (Lammerding et al., 1988; Morales-López et al., 2010).

Positive results have also been obtained in ruminants. Until recently, the most consistent beneficial effect of feeding $S$. cerevisiae to ruminant has been stabilization of the rumen $\mathrm{pH}$ or prevention of acidosis caused by rapid fermentation of large quantities of carbohydrates (Chiquette, 2009). It has been demonstrated in vitro that $S$. cerevisiae can stimulate the digestion of cellulose by cellulolytics organisms such as Fibrobacter succinogenes and Ruminococcus flavefaciens and promotes the utilization of lactate by Megasphaera elsdenii and Selenomonas ruminantium (Callaway and Martin, 1997). It is also well known that feeding yeast stimulates rumen microbial growth and oxygen scavenging, thus creating more favorable conditions for anaerobic microorganisms (Fonty and Chaucheyras-Durand, 2006). Finally, the mode of action of probiotic yeast in the rumen depends on several factors such as yeast strain, viability, and the composition of the diet of the animal (Chiquette, 2009).

The applications of yeasts in human foods and animal feeds as well as in agriculture and other sectors are increasing and market demand is providing motivation to continue or even increase research and development in this field. Only future studies will reveal the ultimate potential of these microorganisms in different fields of application.

\section{ACKNOWLEDGMENTS}

Support for this research was received in the form of grants from the Fonds de recherche sur la nature et les technologies Québec (FQRNT), the Ministère de l'Agriculture, des Pêcheries et de l'Alimentation du Québec (MAPAQ), Novalait, and Agriculture and Agri-Food Canada (AAC). The authors thank Dr. Stephen Davids for critical reading of the manuscript and Riadh Hammami for the technical support. 


\section{REFERENCES}

Adam, J., Barret, A., and Barret-Bellet, C. (1976). Essai clinique controle en double issu de l'ultra levure lyophilisee. Med. Chir. Digest. 5, 401-406.

Alexandre, H., Costello, P. J., Remize, F., Guzzo, J., and GuillouxBenatier, M. (2004). Saccharomyces cerevisiae - Oenococcus oeni interactions in wine: current knowledge and perspectives. Int. J. Food Microbiol. 93, 141-154.

Almeida, M. J., and Pais, C. (1996). Leavening ability and freeze tolerance of yeasts isolated from traditional corn and rye bread doughs. Appl. Environ. Microbiol. 62, 4401-4404.

Anupama, X., and Ravindra, P. (2000). Value-added food: single cell protein. Biotechnol. Adv. 18, 459-479.

Asehraou, A., Peres, C., Brito, D., Faid, M., and Serhrouchni, M. (2007). Characterization of yeast strains isolated from bloaters of fermented green table olives during storage. Grasas Aceites 51, 225-229.

Bekatorou, A., Psarianos, C., and Koutinas, A. A. (2006). Production of food grade yeasts. Biopolymers 44, 407-415.

Besirbellioglu, B. A., Ulcay, A., Can, M., Erdem, H., Tanyuksel, M., Avci, I. Y., et al. (2006). Saccharomyces boulardii and infection due to Giardia lamblia. Scand. J. Infect. Dis. 38, 479-481.

Bevan, E. A., and Somers, J. M. (1969). Somatic segregation of the killer $(\mathrm{k})$ and neutral (n) cytoplasmic genetic determinants in yeast. Genet. Res. 14, 71-77.

Bilinski, C. A., and Casey, G. P. (1989). Developments in sporulation and breeding of brewer's yeast. Yeast 5, 429-438.

Billoo, A. G., Memon, M. A., Khaskheli, S. A., Murtaza, G., Iqbal, K., Saeed Shekhani, M., et al. (2006). Role of a probiotic (Saccharomyces boulardii) in management and prevention of diarrhoea. World J. Gastroenterol. 12, 4557-4560.

Bisson, J.-F., Hidalgo, S., Rozan, P., and Messaoudi, M. (2010). Preventive effects of different probiotic formulations on travelers' diarrhea model in wistar rats: preventive effects of probiotics on TD. Dig. Dis. Sci. 55, 911-919.

Blanquet, S., Marol-Bonnin, S., Beyssac, E., Pompon, D., Renaud, M., and Alric, M. (2001). The biodrug concept: an innovation approach to therapy. Trends Biotechnol. 19, 393-400.

Bleichner, G., Bléhaut, H., Mentec, H., and Moyse, D. (1997). Saccharomyces boulardii prevents diarrhea in critically ill tube-fed patients. Intensive Care Med. 23, 517-523.

Boone, C., Sdicu, A., Degri, R., Sanchez, C., and Bussey, H. (1990). Integration of the yeast "KI" killer toxin in gene into the genome of marked wine yeasts and its effect on vinification. Yeast 41, 37-42.

Bortol, A., Nudel, C., Fraile, E., Torres, R., Giulietti, A., Spencer, J. F. T., et al. (1986). Isolation of yeast with killer activity and its breeding with an industrial baking strain by protoplast fusion. Appl. Microbiol. Biotechnol. 24, 414-416.

Bradley, G. L., Savage, T. F., and Timm, K. I. (1994). The effects of supplementing diets with Saccharomyces cerevisiae var. boulardii on male poult performance and ileal morphology. Poult. Sci. 73, 1766-1770.

Bravo, M. V., Bunout, D., Leiva, L., De La Maza, M. P., Barrera, G., De La Maza, J., et al. (2008). Effect of probiotic Saccharomyces boulardii on prevention of antibiotic-associated diarrhea in adult outpatients with amoxicillin treatment. Rev. Med. Chil. 136, 981-988.

Buts, J.-P. (2009). Twenty-five years of research on Saccharomyces boulardii trophic effects: updates and perspectives. Dig. Dis. Sci. 54, 15-18.

Buts, J.-P., and Bernasconi, P. (2005). Saccharomyces boulardii: basic science and clinical applications in gastroenterology. Gastroenterol. Clin. North Am. 34, 515-532.

Callaway, E. S., and Martin, S. A. (1997). Effects of a Saccharomyces cerevisiae culture on ruminal bacteria that utilize lactate and digest cellulose. J. Dairy Sci. 80, 2035-2044.

Can, M., Besirbellioglu, B. A., Avci, I. Y., Beker, C. M., and Pahsa, A. (2006). Prophylactic Saccharomyces boulardii in the prevention of antibiotic-associated diarrhea: a prospective study. Med. Sci. Monit. 12, PI19-PI22.

Castagliuolo, I., LaMont, J. T., Nikulasson, S. T., and Pothoulakis, C. (1996). Saccharomyces boulardii protease inhibits Clostridium difficile toxin A effects in the rat ileum. Infect. Immun. 64, 5225-5232.

Castagliuolo, I., Riegler, M. F., Valenick, L., LaMont, J. T., and Pothoulakis, C. (1999). Saccharomyces boulardii protease inhibits the effects of Clostridium difficile toxins $\mathrm{A}$ and $\mathrm{B}$ in human colonic mucosa. Infect. Immun. 67, 302-307.

Castex, F., Corthier, G., Jouvert, S., Elmer, G. W., Lucas, F., and Bastide, M. (1990). Prevention of Clostridium difficile-induced experimental pseudomembranous colitis by Saccharomyces boulardii: a scanning electron microscopic and microbiological study. J. Gen. Microbiol. 136, 1085-1089.

Cavalero, D. A., and Cooper, D. G. (2003). The effect of medium composition on the structure and physical state of sophorolipids produced by Candida bombicola ATCC 22214 J. Biotechnol. 103, 31-41.

Chaffin, W. L., López-Ribot, J. L., Casanova, M., Gozalbo, D., and Martínez, J. P. (1998). Cell wall and secreted proteins of Candida albicans: identification, function, and expression. Microbiol. Mol. Biol. Rev. 62, 130-180.

Chen, L.-S., Ma, Y., Maubois, J.-L., He, S.-H., Chen, L.-J., and Li, H.-M. (2010). Screening for the potential probiotic yeast strains from raw milk to assimilate cholesterol. Dairy Sci. Technol. 90, 537-548.

Chen, W.-B., Han, Y.-F., Jong, S.-C., and Chang, S.-C. (2000). Isolation, purification, and characterization of a killer protein from Schwanniomyces occidentalis. Appl. Environ. Microbiol. 66, 1029-1035.

Chiquette, J. (2009). Evaluation of the protective effect of probiotics fed to dairy cows during a subacute ruminal acidosis challenge. Anim. Feed Sci. Technol. 153, 278-291.

Ciani, M., and Fatichenti, F. (2001). Killer toxin of Kluyveromyces phaffii DBVPG 6076 as a biopreservative agent to control apiculate wine yeasts. Appl. Environ. Microbiol. 67, 3058-3063.

Cindoruk, M., Erkan, G., Karakan, T., Dursun, A., and Unal, S. (2007). Efficacy and safety of Saccharomyces boulardii in the 14-day triple anti-Helicobacter pylori therapy: a prospective randomized placebocontrolled double-blind study. Helicobacter 12, 309-316.

Comitini, F., De Ingeniis, J., Pepe, L., Mannazzu, I., and Ciani, M. (2004a). Pichia anomala and Kluyveromyces wickerhamii killer toxins as new tools against Dekkera/Brettanomyces spoilage yeasts. FEMS Microbiol. Lett. 238, 235-240.

Comitini, F., Di Pietro, N., Zacchi, L. Mannazzu, I., and Ciani, M. (2004b). Kluyveromyces phaffii killer toxin active against wine spoilage yeasts: purification and characterization. Microbiology 150, 2535-2541.

Conti, S., Magliani, W., Arseni, S., Frazzi, R., Salati, A., Ravanetti, L., et al. (2002). Inhibition by yeast killer toxin-like antibodies of oral Streptococci adhesion to tooth surfaces in an ex vivo model. Mol. Med. 8, 313-317.

Coté, G. A., and Buchman, A. L. (2006). Antibiotic-associated diarrhoea. Expert Opin. Drug. Saf. 5, 361-372.

Cremonini, F., Di Caro, S., Covino, M., Armuzzi, A., Gabrielli, M., Santarelli, L., et al. (2002). Effect of different probiotic preparations on antiHelicobacter pylori therapy-related side effects: a parallel group, triple blind, placebo-controlled study. Am. J. Gastroenterol. 97, 2744-2749.

Czerucka, D., Piche, T., and Rampal, P. (2007). Review article: yeast as probiotics - Saccharomyces boulardii. Aliment. Pharmacol. Ther. 26, 767-778.

Czerucka, D., and Rampal, P. (2002). Experimental effects of Saccharomyces boulardii on diarrheal pathogens. Microbes Infect. 4, 733-739.

Dalmasso, G., Cottrez, F., Imbert, V., Lagadec, P., Peyron, J.-F., Rampal, P., et al. (2006a). Saccharomyces boulardii inhibits inflammatory bowel disease by trapping $\mathrm{T}$ cells in mesenteric lymph nodes. Gastroenterology 131, 1812-1825.

Dalmasso, G., Loubat, A., Dahan, S., Calle, G., Rampal, P., and Czerucka, D. (2006b). Saccharomyces boulardii prevents TNF-alpha-induced apoptosis in EHEC-infected T84 cells. Res. Microbiol. 157, 456-465.

Dawes, E. A. (1986). Microbial energetics. Biochem. Educ. 95, 187.

Dawson, K. A., Newman, K. E., and Boling, J. A. (1990). Effects of microbial supplements containing yeast and lactobacilli on roughage-fed ruminal microbial activities. J. Anim. Sci. 68, 3392-3398.

Deak, T. (2006). "Environmental factors influencing yeasts," in Biodiversity and Ecophysiology of Yeasts (The Yeast Handbook series), eds G. Péter and C. Rosa (Berlin: Springer), 155-174.

DeMeo, M., Kolli, S., Keshavarzian, A., Borton, M., Al-Hosni, M., Dyavanapalli, M., et al. (1998). Beneficial effect of a bile acid resin binder on enteral feeding induced diarrhea. Am. J. Gastroenterol. 93, 967-971.

Dickinson, J., and Kruckeberg, A. (2006). "Carbohydrate metabolism," in Yeasts in Food and Beverages, eds A. Querol and G. Fleet (Berlin: Springer), 215-242.

Dieuleveux, V., Van Der Pyl, D., Chataud, J., and Gueguen, M. (1998). Purification and characterization of anti-Listeria compounds produced by Geotrichum candidum. Appl. Environ. Microbiol. $64,800-803$. 
D’Souza, A. L., Rajkumar, C., Cooke, J., and Bulpitt, C. J. (2002). Probiotics in prevention of antibiotic associated diarrhoea: meta-analysis. $B M$ ) 324, 1361.

Duman, D. G., Bor, S., Ozütemiz, O., Sahin, T., Oguz, D., Istan, F., et al. (2005). Efficacy and safety of Saccharomyces boulardii in prevention of antibiotic-associated diarrhoea due to Helicobacter pylori eradication. Eur. J. Gastroenterol. Hepatol. 17, 1357-1361.

Edens, F. W. (2003). An alternative for antibiotic se in poultry: probiotics. Rev. Bras. Cienc. Avic. 5, 75-97.

Elmer, G. W., and Corthier, G. (1991). Modulation of Clostridium difficile induced mortality as a function of the dose and the viability of the Saccharomyces boulardii used as a preventative agent in gnotobiotic mice. Can. J. Microbiol. 37, 315-317.

Elmer, G. W., and McFarland, L. V. (1987). Suppression by Saccharomyces boulardii of toxigenic Clostridium difficile overgrowth after vancomycin treatment in hamsters. Antimicrob. Agents Chemother. 31, 129-131.

Elmer, G. W., McFarland, L. V., Surawicz, C. M., Danko, L., and Greenberg, R. N. (1999). Behaviour of Saccharomyces boulardii in recurrent Clostridium difficile disease patients. Aliment. Pharmacol. Ther. 13, 1663-1668.

El-neshawy, S. M., and Wilson, C. L. (1997). Nisin enhancement of biocontrol of postharvest diseases of apple with Candida oleophila. Postharvest Biol. Technol. 10, 9-14.

Erdeve, O., Tiras, U., and Dallar, Y. (2004). The probiotic effect of Saccharomyces boulardii in a pediatric age group. J. Trop. Pediatr. 50, 234-238.

Etienne-Mesmin, L., Livrelli, V., Privat, M., Denis, S., Cardot, J.-M., Alric, M., et al. (2011). Effect of a new probiotic Saccharomyces cerevisiae strain on survival of Escherichia coli O157:H7 in a dynamic gastrointestinal model. Appl. Environ. Microbiol. 77, 1127-1131.

Fatichenti, F., Bergere, J. L., Deiana, P., and Farris, G. A. (1983). Antagonistic activity of Debaryomyces hansenii towards Clostridium tyrobutyricum and C. butyricum. J. Dairy Res. 50, 449-457.

Fleet, G. H. (2007). Yeasts in foods and beverages: impact on product quality and safety. Curr. Opin. Biotechnol. 18, 170-175.

Foligné, B., Dewulf, J., Vandekerckove, P., Pignède, G., and Pot, B. (2010). Probiotic yeasts: anti-inflammatory potential of various non-pathogenic strains in experimental colitis in mice. World J. Gastroenterol. 16, 2134-2145.

Fonty, G., and Chaucheyras-Durand, F. (2006). Effects and modes of action of live yeasts in the rumen. Biologia 61, 741-750.

Fredlund, E., Blank, L. M., Schnürer, J., Sauer, U., and Passoth, V. (2004). Oxygen- and glucose-dependent regulation of central carbon metabolism in Pichia anomala. Appl. Environ. Microbiol. 70, 5905-5911.

Gao, J., Zhang, H. J., Yu, S. H., Wu, S. G., Yoon, I., Quigley, J., et al. (2008). Effects of yeast culture in broiler diets on performance and immunomodulatory functions. Poult. Sci. 87, 1377-1384.

Ghoneum, M., Wang, L., Agrawal, S., and Gollapudi, S. (2007). Yeast therapy for the treatment of breast cancer: a nude mice model study. In vivo 21, 251-258.

Gobbetti, M., Corsetti, A., and Rossi, J. (1994). The sourdough microflora. Interactions between lactic acid bacteria and yeasts: metabolism of carbohydrates. Appl. Microbiol. Biotechnol. 41, 456-460.

Goerges, S., Aigner, U., Silakowski, B., and Scherer, S. (2006). Inhibition of Listeria monocytogenes by foodborne yeasts. Appl. Environ. Microbiol. 72, 313-318.

Goerges, S., Koslowsky, M., Velagic, S., Borst, N., Bockelmann, W., Heller, K. J., et al. (2011). Anti-listerial potential of food-borne yeasts in red smear cheese. Int. Dairy J. 21, 83-89.

Goldman, E. (2008). Practical Handbook of Microbiology, 2nd Edn, eds. E. Goldman and L. Green (CRC Press). Available at: http://www.crcnetbase.com/doi/ book/10.1201/9781420009330.

Golowczyc, M. A., Mobili, P., Garrote, G. L., de los Angeles Serradell, M., Abraham, A. G., and De Antoni, G. L. (2009). Interaction between Lactobacillus kefir and Saccharomyces lipolytica isolated from kefir grains: evidence for lectin-like activity of bacterial surface proteins. J. Dairy Res. 76, 111-116.

Golubev, W. I. (2006). "Antagonistic interactions among yeasts," in Biodiversity and Ecophysiology of Yeasts, eds. G. Péter and C. Rosa (Berlin: Springer), 197-219.

Gunge, N., Tamaru, A., Ozawa, F., and Sakaguchi, K. (1981). Isolation and characterization of linear deoxyribonucleic acid plasmids from Kluyveromyces lactis and the plasmid- associated killer character. Yeast 145, 382-390.

Guslandi, M., Giollo, P., and Testoni, P. A. (2003). A pilot trial of Saccharomyces boulardii in ulcerative colitis. Eur. J. Gastroenterol. Hepatol. 15, 697-698.

Guslandi, M., Mezzi, G., Sorghi, M., and Testoni, P. A. (2000). Saccharomyces boulardii in maintenance treatment of Crohn's disease. Dig. Dis. Sci. 45, 1462-1464.

Halász, A., and Lásztity, R. (1991). Use of Yeast Biomass in Food Production. CRC Press, 352. Available at: http://books.google.ca/books?id= xbZRt2pKwqUC

Hara, S., Iimura, Y., and Otsuka, K. (1980). Breeding of useful killer wine yeasts. Am. J. Enol. Vitic. 31, 28-33.

Hatoum, R., Labrie, S., and Fliss, I. (2012). Identification and partial characterization of antilisterial compounds produced by dairy yeasts. Probiotics Antimicrob. Proteins 1-10. doi: 10.1007/s12602-012-9109-8

Hayduck, F. (1909). Uber einen Hefengiftstoff in Hefe. Wochenschr. Brau. 26, 677-679.

Hayman, G. T., and Bolen, P. L. (1991) Linear DNA plasmids of Pichia inositovora are associated with a novel killer toxin activity. Curr. Genet. 19 , 389-393.

Hernández, A., Martín, A., Córdoba, M. G., Benito, M. J., Aranda, E., and Pérez-Nevado, F. (2008). Determination of killer activity in yeasts isolated from the elaboration of seasoned green table olives. Int. J. Food Microbiol. 121, 178-188.

Hibbett, D. S., Binder, M., Bischoff, J. F. Blackwell, M., Cannon, P. F., Eriksson, O. E., et al. (2007). A higherlevel phylogenetic classification of the Fungi. Mycol. Res. 111, 509-547.

Hodgson, V. J., Button, D., and Walker, G. M. (1995). Anti-candida activity of a novel killer toxin from the yeast Williopsis mrakii. Microbiology 141 2003-2012.

Holck, P., Sletmoen, M., Stokke, B. T. Permin, H., and Norn, S. (2007). Potentiation of histamine release by Microfungal $(1 \rightarrow 3)$ - and $(1 \rightarrow 6)$ beta-D-glucans. Basic Clin. Pharmacol. Toxicol. 101, 455-458.

Hooge, D. M. (2004). Meta-analysis of broiler chicken pen trials evaluating dietary mannan oligosaccharide, 1993-2003. Int. J. Poult. Sci. 3, 163-174.

Htwe, K., Yee, K. S., Tin, M., and Vandenplas, Y. (2008). Effect of Saccharomyces boulardii in the treatment of acute watery diarrhea in myanmar children: a randomized controlled study. Am. J. Trop. Med. Hyg. 78, 214-216.

Ibeas, J. I., Lozano, I., Perdigones, L., and Jimenez, J. (1996). Detection of Dekkera/Brettanomyces strains in sherry by a nested PCR method. Appl. Environ. Microbiol. 62, 998-1003.

Izgu, F., and Altinbay, D. (2004). Isolation and characterization of the K5-type yeast killer protein and its homology with an exobeta-1,3-glucanase. Biosci. Biotechnol. Biochem. 68, 685-693.

Izgu, F., Altinbay, D., and Acun, T. (2006). Killer toxin of Pichia anomala NCYC 432; purification, characterization and its exo-beta-1,3glucanase activity. Enzyme Microb. Technol. 39, 669-676.

Jakobsen, M., and Narvhus, J. (1996). Yeasts and their possible beneficial and negative effects on the quality of dairy products. Int. Dairy J. 6 , 755-768.

Kagan, B. L. (1983). Mode of action of yeast killer toxins: channel formation in lipid bilayer membranes. Nature 302, 709-711.

Karen, M., Yuksel, O., Akyürek, N., Ofluoglu, E., Caglar, K., Sahin, T. T., et al. (2010). Probiotic agent Saccharomyces boulardii reduces the incidence of lung injury in acute necrotizing pancreatitis induced rats. J. Surg. Res. 160, 139-144.

Katakura, Y., Sano, R., Hashimoto, T., Ninomiya, K., and Shioya, S. (2010). Lactic acid bacteria display on the cell surface cytosolic proteins that recognize yeast mannan. Appl. Microbiol. Biotechnol. 86, 319-326.

Kawarai, T., Furukawa, S., Ogihara, H., and Yamasaki, M. (2007). Mixedspecies biofilm formation by lactic acid bacteria and rice wine yeasts. Appl. Environ. Microbiol. 73, 4673-4676.

Kelly, C. P., Pothoulakis, C., and LaMont, J. T. (1994). Current concepts: Clostridium difficile colitis. N. Engl. J. Med. 330, 257-262.

Kimura, T., Kitamoto, N., Matsuoka, K., Nakamura, K., Iimura, Y., and Kito, Y. (1993). Isolation and nucleotide sequences of the genes encoding killer toxins from Hansenula mrakii and H. saturnus. Gene 137, 265-270.

Kitamoto, H. K., Hasebe, A., Ohmomo, S., Suto, E. G., Muraki, M., and Iimura, Y. (1999). Prevention of aerobic spoilage of maize silage by a genetically modified killer yeast, Kluyveromyces lactis, defective in the ability to grow on lactic 
acid. Appl. Environ. Microbiol. 65, 4697-4700.

Klein, R. D., and Favreau, M. A. (1995). "The Candida species: biochemistry, molecular biology, and industrial applications," in Food Biothechnology Microorganisms, eds Y. H. Hui and G. G. Khachatourians (New York: VCH publishers), 297-371.

Kollaritsch, H., Holst, H., Grobara, P., and Wiedermann, G. (1993). Prevention of traveler's diarrhea with Saccharomyces boulardii. Results of a placebo controlled doubleblind study. Fortschr. Med. 111, 153-156.

Kono, I., and Himeno, K. (1997). A novel killer yeast effective on Schizosaccharomyces pombe. Biosci. Biotechnol. Biochem. 61, 563-564.

Kotowska, M., Albrecht, P., and Szajewska, H. (2005). Saccharomyces boulardii in the prevention of antibiotic-associated diarrhoea in children: a randomized doubleblind placebo-controlled trial. Aliment. Pharmacol. Ther. 21, 583-590.

Krämer, S., and Bischoff, S. C. (2006). Therapeutic possibilities of probiotics in antibiotic-related diarrhea. MMW Fortschr. Med. 148, 28-30.

Kumura, H., Tanoue, Y., Tsukahara, M., Tanaka, T., and Shimazaki, K. (2004). Screening of dairy yeast strains for probiotic applications. J. Dairy Sci. 87, 4050-4056.

Kurtzman, C. P., Fell, J. W., and Boekhout, T. (2011a). "Definition, classification and nomenclature of the yeasts," in The Yeasts a Taxonomic Study 5 th Edn, eds C. P. Kurtzman, J. W. Fell, and T. Boekhout (Amsterdam: Elsevier Science), 3-9.

Kurtzman, C. P., Fell, J. W., and Boekhout, T. (2011b). The Yeasts: A Taxonomic Study. Elsevier. Available at: http://books.google.ca/books? id=yfg79rlIFIkC

Kurugöl, Z., and Koturoglu, G. (2005). Effects of Saccharomyces boulardii in children with acute diarrhoea. Acta Paediatr. 94, 44-47.

Lammerding, A. M., Garcia, M. M., Mann, E. D., Robinson, Y., Dorward, W. J., Truscott, R. B., et al. (1988). Prevalence of Salmonella and thermophilic Campylobacter in fresh pork, beef, veal and poultry in Canada. J. Food Prot. 51, 47-52.

Lewis, S. J., Potts, L. F., and Barry, R. E. (1998). The lack of therapeutic effect of Saccharomyces boulardii in the prevention of antibioticrelated diarrhoea in elderly patients. J. Infect. 36, 171-174.
Li, J., Li, D., Gong, L., Ma, Y., He, Y., and Zhai, H. (2006). Effects of live yeast on the performance, nutrient digestibility, gastrointestinal microbiota and concentration of volatile fatty acids in weanling pigs. Arch. Anim. Nutr. 60, 277-288.

Line, J. E., Bailey, J. S., Cox, N. A. Stern, N. J., and Tompkins, T. (1998). Effect of yeast-supplemented feed on Salmonella and Campylobacter populations in broilers. Poult. Sci. 77, 405-410.

Liu, S., and Tsao, M. (2010a). Biocontrol of spoilage yeasts and moulds by Williopsis saturnus var. saturnus in yoghurt. Nutr. Food Sci. 40, 166-175.

Liu, S.-Q., and Tsao, M. (2010b). Enhancing stability of lactic acid bacteria and probiotics by Williopsis saturnus var. saturnus in fermented milks. Nutr. Food Sci. 40, 314-322.

Liu, S.-Q., and Tsao, M. (2009a). Biocontrol of dairy moulds by antagonistic dairy yeast Debaryomyces hansenii in yoghurt and cheese at elevated temperatures. Food Control 20, 852-855.

Liu, S.-Q., and Tsao, M. (2009b). Enhancement of survival of probiotic and non-probiotic lactic acid bacteria by yeasts in fermented milk under non-refrigerated conditions. Int. J. Food Microbiol. 135, 34-38.

Liu, S.-Q., and Tsao, M. (2009c). Inhibition of spoilage yeasts in cheese by killer yeast Williopsis saturnus var. saturnus. Int. J. Food Microbiol. 131, 280-282.

Llorente, P., Marquina, D., Santos, A., Peinado, J. M., and Spencer-Martins, I. (1997). Effect of salt on the killer phenotype of yeasts from olive brines. Appl. Environ. Microbiol. 63, 1165-1167.

Lowes, K. F., Shearman, C. A., Payne, J., MacKenzie, D., Archer, D. B., Merry, R. J., et al. (2000). Prevention of yeast spoilage in feed and food by the yeast mycocin HMK. Appl. Environ. Microbiol. 66, 1066-1076.

Lyons, T. P., Jacques, K. A., and Dawson, K. A. (1993). "Miscellaneous products from yeasts," in The Yeasts, 2nd Edn, Vol. 5, eds A. H. Rose and J. S. Harrison (London: Academic), 293-325.

Magliani, W., Conti, S., Frazzi, R. Ravanetti, L., Maffei, D. L., and Polonelli, L. (2005). Protective antifungal yeast killer toxin-like antibodies. Curr. Mol. Med. 5, 443-452.

Magliani, W., Conti, S., Gerloni, M., Bertolotti, D., and Polonelli, L. (1997). Yeast killer systems. Clin. Microbiol. Rev. 10, 369-400.
Magliani, W., Conti, S., Travassos, L. R., and Polonelli, L. (2008). From yeast killer toxins to antibiobodies and beyond. FEMS Microbiol. Lett. 288, 1-8.

Mansour-Ghanaei, F., Dehbashi, N. Yazdanparast, K., and Shafaghi, A. (2003). Efficacy of Saccharomyces boulardii with antibiotics in acute amoebiasis. World J. Gastroenterol. 9 , 1832-1833.

Marquina, D., Peres, C., Caldas, F. V., Marques, J. F., Peinado, J. M., and Spencer-Martins, I. (1992). Characterization of the yeast population in olive brines. Lett. Appl. Microbiol. 14, 279-283.

Marquina, D., Santos, A., and Peinado, J. M. (2002). Biology of killer yeasts. Int. Microbiol. 5, 65-71.

Masih, E. I., and Paul, B. (2002). Secretion of beta-1,3-glucanases by the yeast Pichia membranifaciens and its possible role in the biocontrol of Botrytis cinerea causing grey mold disease of the grapevine. Curr. Microbiol. 44, 391-395.

Masih, E. I., Slezack-Deschaumes, S., Marmaras, I., Barka, E. A., Vernet, G., Charpentier, C., et al. (2001) Characterisation of the yeast Pichia membranifaciens and its possible use in the biological control of Botrytis cinerea, causing the grey mould disease of grapevine. FEMS Microbiol. Lett. 202, 227-232.

McFarland, L. V. (2007). Meta-analysis of probiotics for the prevention of traveler's diarrhea. Travel Med. Infect. Dis. 5, 97-105.

McFarland, L. V. (2010). Systematic review and meta-analysis of Saccharomyces boulardii in adult patients. World J. Gastroenterol. 16, 2202-2222.

McFarland, L. V., Elmer, G. W., and McFarland, M. (2006). Metaanalysis of probiotics for the prevention and treatment of acute pediatric diarrhea. Int. J. Probiotics Prebiotics 1, 63-76.

Mcfarland, L. V., Surawicz, C. M., Greenberg, R. N., Fekety, R., Elmer, G. W., Moyer, K. A., et al. (1994). A randomized placebo-controlled trial combination with standard antibiotics for Clostridium difficile disease. J. Am. Med. Assoc. 271, 1913-1918.

Michalcáková, S., Sulo, P., and Sláviková, E. (1993). Killer yeasts of Kluyveromyces and Hansenula genera with potential application in fermentation and therapy. Acta Biotechnol. 13, 341-350.

Millsap, K. W., Van Der Mei, H. C., Bos, R., and Busscher, H. J. (1998). Adhesive interactions between medically important yeasts and bacteria. FEMS Microbiol. Rev. 21, 321-336.

Morales-López, R., Auclair, E., Van Immerseel, F., Ducatelle, R., García, F., and Brufau, J. (2010). Effects of different yeast cell wall supplements added to maize- or wheat-based diets for broiler chickens. Br. Poult. Sci. 51, 399-408.

Narvhus, J. A., and Gadaga, T. H. (2003). The role of interaction between yeasts and lactic acid bacteria in African fermented milks: a review. Int. J. Food Microbiol. 86, 51-60.

Palpacelli, V., Ciani, M., and Rosini, G. (1991). Activity of different "killer" yeasts on strains of yeast species undesirable in the food industry. FEMS Microbiol. Lett. 68, 75-78.

Patterson, J. A., and Burkholder, K. M. (2003). Application of prebiotics and probiotics in poultry production. Poult. Sci. 82, 627-631.

Pfeiffer, P., and Radler, F. (1984). Comparison of the killer toxin of several yeasts and the purification of a toxin of type K2. Arch. Microbiol. 137, 357-361

Plein, K., and Hotz, J. (1993). Therapeutic effects of Saccharomyces boulardii on mild residual symptoms in a stable phase of Crohn's disease with special respect to chronic diarrhea a pilot study. Z. Gastroenterol. 31, 129-134.

Polonelli, L., Lorenzini, R., De Bernardis, F., and Morace, G. (1986). Potential therapeutic effect of yeast killer toxin. Mycopathologia 96, 103-107.

Polonelli, L., Magliani, W., Ciociola, T., Giovati, L., and Conti, S. (2011). From Pichia anomala killer toxin through killer antibodies to killer peptides for a comprehensive anti-infective strategy. Antonie Van Leeuwenhoek 99, 35-41.

Pothoulakis, C. (2009). Review article: anti-inflammatory mechanisms of action of Saccharomyces boulardii. Aliment. Pharmacol. Ther. 30, 826-833.

Pothoulakis, C., Kelly, C. P., Joshi, M. A., Gao, N., O'Keane, C. J., Castagliuolo, I., et al. (1993). Saccharomyces boulardii inhibits Clostridium difficile toxin A binding and enterotoxicity in rat ileum. Gastroenterology 104, 1108-1115.

Pretorius, I. S. (2000). Tailoring wine yeast for the new millennium: novel approaches to the ancient art of winemaking. Yeast 16, 675-729.

Pretorius, I. S., du Toit, M., and van Rensburg, P. (2003). Designer yeasts for the fermentation industry of the 21st century. Food Technol. Biotechnol. 41, 3-10. 
Psani, M., and Kotzekidou, P. (2006). Technological characteristics of yeast strains and their potential as starter adjuncts in Greekstyle black olive fermentation. World J. Microbiol. Biotechnol. 22, 1329-1336.

Qamar, A., Aboudola, S., Warny, M., Michetti, P., Pothoulakis, C., LaMont, J. T., et al. (2001). Saccharomyces boulardii stimulates intestinal immunoglobulin A immune response to Clostridium difficile toxin A in mice. Infect. Immun. 69, 2762-2765.

Rigothier, M. C., Maccario, J., and Gayral, P. (1994). Inhibitory activity of Saccharomyces yeasts on the adhesion of Entamoeba histolytica trophozoites to human erythrocytes in vitro. Parasitol. Res. 80, 10-15.

Rodrigues, F., Ludovico, P., and Leão, C. (2006). "Sugar metabolism in yeasts: an overview of aerobic and anaerobic glucose catabolism," in The Yeast Handbook, eds. G. Péter and C. Rosa (Berlin: Springer), 101-121.

Romano, P., Capece, A., and Jespersen, L. (2006). "Taxonomic and ecological diversity of food and beverage yeasts," in The Yeast Handbook, eds. A. Querol and G. Fleet (Berlin: Springer), 13-53.

Rosini, G., and Cantini, M. (1987). Killer character in Kluyveromyces yeasts: activity on Kloeckera apiculata. FEMS Microbiol. Lett. 44, 81-84.

Saint-Marc, T., Blehaut, H., Musial, C. and Touraine, T. (1995). Aids-related diarrhea: a double-blind trial of Saccharomyces boulardii. Sem. Hôsp. Paris 71, 735-741.

Santos, A., and Marquina, D. (2004). Ion channel activity by Pichia membranifaciens killer toxin. Yeast 21, 151-162.

Sauerwein, H., Schmitz, S., and Hiss, S. (2007). Effects of a dietary application of a yeast cell wall extract on innate and acquired immunity, on oxidative status and growth performance in weanling piglets and on the ileal epithelium in fattened pigs. $J$. Anim. Physiol. Anim. Nutr. (Berl.) 91, 369-380.

Sazawal, S., Hiremath, G., Dhingra, U., Malik, P., Deb, S., and Black, R. E. (2006). Efficacy of probiotics in prevention of acute diarrhoea: a meta-analysis of masked, randomised, placebo-controlled trials. Lancet Infect. Dis. 6, 374-382.

Schmitt, M. J., and Breinig, F. (2002). The viral killer system in yeast: from molecular biology to application. FEMS Microbiol. Rev. 26, 257-276.
Séguy, N., Polonelli, L., Dei-Cas, E., and Cailliez, J. C. (1998). Effect of a killer toxin of Pichia anomala to Pneumocystis. Perspectives in the control of pneumocystosis. FEMS Immunol. Med. Microbiol. 22, 145-149.

Seki, T., Choi, E.-H., and Ryu, D. (1985). Construction of killer wine yeast strain. Appl. Environ. Microbiol. 49, 1211-1215.

Sezer, A., Usta, U., and Cicin, I. (2009). The effect of Saccharomyces boulardii on reducing irinotecaninduced intestinal mucositis and diarrhea. Med. Oncol. 26, 350-357.

Spadaro, D., and Gullino, M. L. (2004). State of the art and future prospects of the biological control of postharvest fruit diseases. Int. J. Food Microbiol. 91, 185-194.

Suharja, A. A. S., Henriksson, A., and Liu, S.-Q. (2012). Impact of Saccharomyces cerevisiae on viability of probiotic Lactobacillus rhamnosus in fermented milk under ambient conditions. J. Food Process. Preserv. doi:10.1111/j.17454549.2012.00780.x

Surawicz, C. M., Elmer, G. W., Speelman, P., McFarland, L. V., Chinn, J., and Van Belle, G. (1990). Prevention of antibiotic-associated diarrhea by Saccharomyces boulardii: a prospective study. Z. Gastroenterol. $28,259-260$.

Surawicz, C. M., McFarland, L. V., Greenberg, R. N., Rubin, M., Fekety, R., Mulligan, M. E., et al. (2000). The search for a better treatment for recurrent Clostridium difficile disease: use of high-dose vancomycin combined with Saccharomyces boulardii. Oxford University Press. Available at: http://www.ncbi. nlm.nih.gov/pubmed/11049785.

Suzuki, C., Ando, Y., and Machida, S. (2001). Interaction of SMKT, a killer toxin produced by Pichia farinosa, with the yeast cell membranes. Yeast 8, 1471-1478.

Suzuki, C., and Shimma, Y. I. (1999). P-type ATPase spf1 mutants show a novel resistance mechanism for the killer toxin SMKT. Mol. Microbiol. $32,813-823$.

Swanson, K. S., Grieshop, C. M., Flickinger, E. A., Bauer, L. L., Healy, H.-P., Dawson, K. A., et al. (2002a). Supplemental fructooligosaccharides and mannanoligosaccharides influence immune function, ileal and total tract nutrient digestibilities, microbial populations and concentrations of protein catabolites in the large bowel of dogs. J. Nutr. 132, 980-989.

Swanson, K. S., Grieshop, C. M., Flickinger, E. A., Healy, H. P.,
Dawson, K. A., Merchen, N. R., et al. (2002b). Effects of supplemental fructooligosaccharides plus mannanoligosaccharides on immune function and ileal and fecal microbial populations in adult dogs. Arch. Tierernahr. 56, 309-318.

Tanyuksel, M., and Petri, W. A. (2003). Laboratory diagnosis of amebiasis. Society 16, 713-729.

Tasteyre, A., Barc, M.-C., Karjalainen, T., Bourlioux, P., and Collignon, A. (2002). Inhibition of in vitro cell adherence of Clostridium difficile by Saccharomyces boulardii. Microb. Pathog. 32, 219-225.

Tempé, J. D., Steidel, A. L., Blehaut, H., Hasselmann, M., Lutun, P., and Maurier, F. (1983). Prevention of diarrhea administering Saccharomyces boulardii during continuous enteral feeding. Sem. Hop. 59, 1409-1412.

Todd, B. E. N., Fleet, G. H., and Henschke, P. A. (2000). Promotion of autolysis through the interaction of killer and sensitive yeasts: potential application in sparkling wine production. Am. J. Enol. Vitic. 51, 65-72.

Valdés-Stauber, N., Scherer, S., and Seiler, H. (1997). Identification of yeasts and coryneform bacteria from the surface microflora of brick cheeses. Int. J. Food Microbiol. 34 115-129.

Van Der Aa Kühle, A., and Jespersen, L. (2003). The taxonomic position of Saccharomyces boulardii as evaluated by sequence analysis of the D1/D2 domain of 26S rDNA the ITS1-5.8S rDNA-ITS2 region and the mitochondrial cytochromec oxidase II gene. Syst. Appl. Microbiol. 26, 564-571.

Van Der Aa Kühle, A., Skovgaard, K., and Jespersen, L. (2005). In vitro screening of probiotic properties of Saccharomyces cerevisiae var. boulardi and food-borne Saccharomyces cerevisiae strains. Int. J. Food Microbiol. 101, 29-39.

Van Dijken, J. P., and Scheffers, W. A. (1986). Redox balances in the metabolism of sugars by yeasts. FEMS Microbiol. Lett. 32, 199-224.

van Heugten, E., Funderburke, D. W., and Dorton, K. L. (2003). Growth performance, nutrient digestibility, and fecal microflora in weanling pigs fed live yeast. J. Anim. Sci. 81, 1004-1012.

Van Vuuren, H. J. J., and Jacobs, C. J. (1992). Killer yeasts in the wine industry: a review. Am. J. Enol. Vitic. $43,119-128$.

Vandenplas, Y., Brunser, O., and Szajewska, H. (2009). Saccharomyces boulardii in childhood. Eur. J. Pediatr. 168, 253-265.

Viljoen, B. (2006). "Yeast ecological interactions. Yeast'yeast, yeast'bacteria, yeast'fungi interactions and yeasts as biocontrol agents," in Yeasts in Food and Beverages, eds. A. Querol and G. Fleet (Berlin: Springer), 83-110.

Viljoen, B. C. (2001). The interaction between yeasts and bacteria in dairy environments. Int. J. Food Microbiol. 69, 37-44.

Villarruel, G., Rubio, D. M., Lopez, F., Cintioni, J., Gurevech, R., Romero, G., et al. (2007). Saccharomyces boulardii in acute childhood diarrhoea: a randomized, placebocontrolled study. Acta Paediatr. 96, 538-541.

Walker, G. M., McLeod, A. H., and Hodgson, V. J. (1995). Interactions between killer yeasts and pathogenic fungi. FEMS Microbiol. Lett. 127, 213-222.

Webster, J., and Weber, R. (2007). Introduction to Fungi. Cambridge University Press. Available at: http://books.google.ca/books?id= HZLXFi-om-0C

Weiler, F., and Schmitt, M. J. (2003). Zygocin, a secreted antifungal toxin of the yeast Zygosaccharomyces bailii, and its effect on sensitive fungal cells. FEMS Yeast Res. 3, 69-76.

Whelan, K. (2007). Enteral-tubefeeding diarrhoea: manipulating the colonic microbiota with probiotics and prebiotics. Proc. Nutr. Soc. 66, 299-306.

White, J. H., Butler, A. R., and Stark, M. J. R. (1989). Kluyveromyces lactis toxin does not inhibit yeast adenylyl cyclase. Nature 341, 666-668.

Wickner, R. B. (1996). Double-stranded RNA viruses of Saccharomyces cerevisiae. Microbiol. Rev. 60, 250-265.

Wijsman, M. R., Van Dijken, J. P., Van Kleeff, B. H., and Scheffers, W. A. (1984). Inhibition of fermentation and growth in batch cultures of the yeast Brettanomyces intermedius upon a shift from aerobic to anaerobic conditions (Custers effect). Antonie Van Leeuwenhoek 50, 183-192.

Wyder, M., and Puhan, Z. (1999). Role of selected yeasts in cheese ripening: an evaluation in aseptic cheese curd slurries. Int. Dairy J. 9, 3-10.

Xie, N., Zhou, T., and Li, B. (2012). Kefir yeasts enhance probiotic potentials of Lactobacillus paracasei H9: the positive effects of coaggregation between the two strains. Food Res. Int. 45, 394-401. 
Yoshiuchi, K., Watanabe, M., and Nishimura, A. (2000). Breeding of a non-urea producing sake yeast with killer character using a kar1-1; mutant as a killer donor. J. Ind. Microbiol. Biotechnol. 24, 203-209.

Young, T. W. (1981). The genetic manipulation of killer character into brewing yeast. J. Inst. Brew. 87, 292-295.

Young, T. W., and Yagiu, M. (1978). A comparison of the killer character in different yeasts and its classification. Antonie Van Leeuwenhoek 44, 59-77.

Zhang, A. W., Lee, B. D., Lee, S. K., Lee, K. W., An, G. H., Song, K. B., et al. (2005). Effects of yeast (Saccharomyces cerevisiae) cell components on growth performance, meat quality, and ileal mucosa development of broiler chicks. Poult. Sci. 84, 1015-1021.

Conflict of Interest Statement: The authors declare that the research was conducted in the absence of any commercial or financial relationships that could be construed as a potential conflict of interest.

Received: 06 August 2012; accepted: 21 November 2012; published online: 19 December 2012.

Citation: Hatoum R, Labrie S and Fliss I (2012) Antimicrobial and probiotic properties of yeasts: from fundamental to novel applications. Front. Microbio. 3:421. doi 10.3389/fmicb.2012.00421
This article was submitted to Frontiers in Food Microbiology, a specialty of Frontiers in Microbiology.

Copyright (C) 2012 Hatoum, Labrie and Fliss. This is an open-access article distributed under the terms of the Creative Commons Attribution License, which permits use, distribution and reproduction in other forums, provided the original authors and source are credited and subject to any copyright notices concerning any third-party graphics etc. 